\title{
PATHOPHYSIOLOGICAL ASPECTS OF EMBRYONIC MORTALITY IN DAIRY COWS
}

\section{A.G. NEZHDANOV', V.I. MIKHALEV', E.G. LOZOVAYA², K.A. LOBODIN², V.A. SAFONOV 3}

\author{
${ }^{1}$ All-Russian Veterinary Research Institute of Pathology, Pharmacology and Therapy, Federal Agency of Scientific \\ Organizations, 114b, ul. Lomonosova, Voronezh, 394087 Russia, e-mail vnivipat@mail.ru; \\ ${ }^{2}$ Emperor Peter the Great Voronezh State Agricultural University, 114a, ul. Lomonosova, Voronezh, 394087 Russia, e- \\ mail 1lozovaja@yandex.ru (corresponding author); \\ ${ }^{3}$ V.I. Vernadsky Institute of Geochemistry and Analytical Chemistry, Federal Agency of Scientific Organizations, 19, \\ Kosygina, Moscow, 119991 Russia, e-mail safrus2003@mail.ru \\ The authors declare no conflict of interests \\ Received December 30, 2016
}

\section{Abstract}

Early embryonic mortality and its high frequency in lactating cows are among the causes for a decrease of animal performance, reproduction, and the effectiveness of modern dairy cattle industry as a whole. The aim of this research was to reveal pathogenic significance of maternal endocrine, metabolic and immune risk factors for occurrence of this pathology. The surveys involved black-motley cows with average annual productivity of 6.4-7.6 ths. kg. Pregnancy and embryonic mortality were diagnosed on days 19 to 23,28 to 32 , and 38 to 45 after artificial insemination by transrectal ultrasound examination with the use of an ultrasonic scanner Easi-Scan-3 (Great Britain). Venous blood samples were collected during the same periods. Blood progesterone, estradiol-17 $\beta$, testosterone, proteins, total immunoglobulins, circulating immune complexes, urea, creatinine, cholesterol, glucose, vitamins $\mathrm{E}$ and $\mathrm{C}$, total calcium, inorganic phosphorus, protein-bound iodine, magnesium, zinc, copper, manganese, selenium, middle molecular peptides, malonic dialdehyde, alkaline phosphatase activity, alanine aminotransferase, aspartate aminotransferase, gamma-glutamyl transferase, catalase, bactericidal and lysozyme activity of blood serum, morphological blood composition were assessed with the use of a biochemical analyzer Hitahi-902 (Japan), a spectrophotometer UV 1700 (Japan), an atomic adsorptive spectrometer Perkin Elmer-703 (USA), a hematology analyzer ABX Micros 60 (France), and spectrum analyzer Uniplan (Russia). The blood parameters were tested in 18 animals, 9 ones with physiological embryo formation (control) and 9 ones with embryo death. It was found out that embryonic death is firstly associated with an endocrine insufficiency of sex glands of the mother cows, as reflected by blood progesterone and estradiol-17 $\beta$ level which at various stages of gestation was lower by $12.0-43.3 \%$ and $45.0-85.5 \%$, respectively, when compared to the animals of control group. Under embryonic death, the mother cows' metabolic profile was characterized by an increase in blood concentration of protein (by 3.2-5.4\%), urea (by 9.8-23.6\%), creatinine (by 10.1$13.5 \%$ ), cholesterol (by 10.9-17,1 \%), middle molecular peptides (by 6.1-34.7 \%). Blood alkaline phosphatase activity was higher by $12.8-36.2 \%$, alanine aminotransferase - by 3.6-13.2 \%, aspartate aminotransferase - by 13.8-30.8\%, gamma-glutamyl transferase - by $45.4-77.5 \%$, and endogenous intoxication index increased by $13.0-40.0 \%$ that was a reflection of liver and kidney insufficiency, cholestasis syndrome manifestation and endogenous intoxication. The pathology was related to the deficiency of essential bioelements, increased lipid peroxidation (LPO), decreased function of antioxidant protection (AOP) system, accumulation of LPO toxic products and oxidative stress development. Under embryo death, blood zinc concentration was 9.7-27.2\% less, copper concentration 17.6-23.3 \% less, manganese $-10.8-15.2 \%$ less, selenium $-16.3-29.1 \%$ less, protein-bound iodine amount $-7.3-33.4 \%$ less, magnesium - 9.7-27.4 \% less, glutathione peroxidase activity -25.8 $31.2 \%$ lower, catalase - 26.5-51.2 \% lower, vitamin E - 26.3-31.6 \% lower, and vitamin C 25.1-57.1\% lower, as compared to the control animals. The changes in immune status of mother cows with embryonic mortality manifested themselves by an increase in the number of blood leukocytes, their neutrophilic and eosinophilic forms, monocytes, by a decrease in phagocytic activity, the number of lymphocytes, immunoglobulins, bactericidal activity and lysozyme activity in blood serum, and also by vaginal dysbiosis. The conclusion is that diselementosis, oxidative stress and endogenous intoxication, endocrine and immune insufficiency are determinant pathophysiological factors in multiple-factor etiology of early embryonic mortality.

Keywords: cows, embryonic mortality, diselementosis, oxidative stress, endogenous intoxi- 
In lactating cows, fetal mortality becomes one of the urgent problems of modern dairy cattle breeding. The frequency of this pathology varies from 20 to $45 \%$ [1-5] and rises with the increase in milk productivity [6-8] accompanied by a profound rearrangement of endocrine, metabolic and immune homeostasis. According to some papers [6, 7], it can be 48-55\%. S.V. Belik (8) reported early embryo loss in $33 \%, 43 \%$ and $67 \%$ cows with a milk yield up to 6 ths. $\mathrm{kg}$, 6-7 ths. $\mathrm{kg}$, and over 7 ths. $\mathrm{kg}$, respectively.

Over the past decades, the dairy productivity in cows increased from 4-5 to 8-11 ths. $\mathrm{kg}$, while their fertility in the first insemination, clinically diagnosed after 50-60 days, decreased from 60-65 to 32-35\% [9-12]. The increase in embryonic death leads to a decrease in fertility, the rate of reproduction and total profitability of dairy farming. Therefore, study pathogenetic significance of the maternal risk factors of this pathology has both scientific and practical importance.

In this work, for the first time we carried out a complex assessment of hormonal, metabolic and immune indicators in lactating cows at early gestation during normal embryo development and its death. It is shown that diselementosises, oxidative stress, endogenous intoxication, endocrine immune deficiency are of pathogenetic significance for embryonic development.

The aim of the work is to identify the role of endocrine, metabolic and immune disorders in lactating cows in embryonic mortality at early gestation.

Technique. Experiments were carried out in the winter 2014 at OOO SP Vyaznovatovka (Nizhnedevitsky Region, Voronezh Province) on black-and-white cows (a total of 32 lactating cows) with an average annual milk productivity of 6.4-7.6 ths $\mathrm{kg}$ at tethered farming technology. Animal diet included corn silage $(25 \mathrm{~kg})$, sainfoin hay $(3 \mathrm{~kg})$, straw barley $(3 \mathrm{~kg})$, grain mixture $(7 \mathrm{~kg})$, sunflower meal $(1 \mathrm{~kg})$. The daily intake of food was $17.6 \mathrm{~kg}$ dry matter $(1 \mathrm{~kg}$ contained $5.5 \mathrm{~g}$ of calcium, $4.0 \mathrm{~g}$ of phosphorus, $2.3 \mathrm{~g}$ of magnesium, $7.2 \mathrm{mg}$ of copper, $33.0 \mathrm{mg}$ of zinc, 34, $5 \mathrm{mg}$ of manganese, $0.18 \mathrm{mg}$ of selenium, $0.37 \mathrm{mg}$ of iodine).

Pregnancy and embryonic loss was detected on days 19-23, 28-32, and 38-45 after artificial insemination by transrectal echographic examination with an ultrasound scanner Easi-Scan-3 (BCF Technologi, Great Britain) with linear sensor 4, 5-8.5 MHz [13]. In the same gestation period, venous blood from the cows with physiological embryo formation $(n=9$, control) and those with recorded embryonic death $(n=9)$ was collected for laboratory tests.

The concentration of sex hormones (progesterone, estradiol-17 $\beta$, testosterone) was determined in the blood serum by solid-phase enzyme immunoassay using commercial test systems (OOO Hema-Medica, Russia) and an enzyme immunoassay analyzer Uni-plan AIFR-1 (ZAO Pikon, Russia) in accordance with the manufacturers' instructions.

Serum and whole blood levels of proteins, total immunoglobulins, urea, creatinine, cholesterol, glucose, vitamins $\mathrm{E}$ and $\mathrm{C}$, total calcium, inorganic phosphorus, protein-bound iodine (PBI), middle molecule peptides (MMP), malonic dialdehyde (MDA), alkaline phosphatase (ALP), alanine aminotransferase (ALT), aspartate aminotransferase (AST), $\gamma$-glutamyl transferase (GGT), glutathione peroxidase (GPO), catalase were assessed by standard methods for studying metabolic parameters [14] on a biochemical analyzer Hitahi-902 (Roche Diagnostics GmbH, Germany-Japan) and spectrophotometer UV 1700 (Shimadzu Corp., Japan); zinc, copper, manganese, selenium, magnesium was estimated using an atomic adsorption spectrometer Perkin Elmer-703 (PerkinElmer, USA), blood morphology was studied on a hemoanalyzer ABX Micros 60 (ABX Diagnostics, France). Blood bactericidal (BA) and lysozyme activity (LA), circulating immune complexes (CIC) were determined according to guidelines for 
assessing and correcting immune status in animals [15]. In cervical-vaginal mucus, general bacterial contamination, the titer of entero-, lacto- and bifidobacteria, and fungal infection were determined by common microbiological methods.

For processing the Statistica 8.0 software (StatSoft Inc., USA) was used. The data are presented as mean values $(X)$ and the error $(x)$. Differences were considered statistically significant at $\mathrm{p}<0.05$.

Results. The embryo death was recorded in cows with functional insufficiency of the gonads (Table 1). Thus, in cows that lost embryos at different stages of gestation the blood progesterone level was 12.0-43.3 \% lower than in the control. In mother-cows this indicator, as compared to the initial values, increased by $28.8 \%$ in normal gestation and decreased by $18.0 \%$ at embryonic loss.

1. Concentration of blood sex hormones in black-and-white cows in normal gestation and at embryonic loss $(X \pm x$, OOO SP Vyaznovatovka, Nizhnedevitsky Region, Voronezh Province, 2014)

\begin{tabular}{|c|c|c|c|}
\hline \multirow{2}{*}{ Hormone } & \multicolumn{3}{|c|}{ Gestation, days } \\
\hline & $19-23$ & $28-32$ & $38-45$ \\
\hline Progesterone, $\mathrm{nmol} / 1$ & $31.6 \pm 3.61 / 27.8 \pm 2.84$ & $40.7 \pm 6.17 / 24.2 \pm 2.81^{*}$ & $40.2 \pm 5.06 / 22.8 \pm 3.33^{* *}$ \\
\hline Testosterone, nmol/1 & $1.63 \pm 0.21 / 1.78 \pm 0.37$ & $2.08 \pm 0.28 / 1.96 \pm 0.40$ & $2.86 \pm 0.56 / 1.15 \pm 0.17 *$ \\
\hline Estradiol-17 $\beta, \mathrm{pmol} / \mathrm{l}$ & $146.2 \pm 26.2 / 78.8 \pm 22.6$ & $117.3 \pm 10.5 / 80.9 \pm 5.5^{*}$ & $142.1 \pm 14.6 / 40.4 \pm 7.0^{* *}$ \\
\hline
\end{tabular}

Developing hypoprogesteronemia entails not only the inferiority of the secretory transformation of the endometrium and the supply of nutrients to the developing embryo, but also an increase in the aggressiveness of peripheral mononuclear cells (lymphocytes, monocytes) and endometrial macrophages against embryonic tissues through Ig synthesis, oxygen explosion in macrophages and stimulation of the production of anti-inflammatory cytokines [15-20].

2. Blood biochemical indicators in black-and-white cows in normal gestation and at embryonic loss $(X \pm x$, OOO SP Vyaznovatovka, Nizhnedevitsky Region, Voronezh Province, 2014)

\begin{tabular}{|c|c|c|c|}
\hline \multirow{2}{*}{ Parameter } & \multicolumn{3}{|c|}{ Gestation, days } \\
\hline & $19-23$ & $28-32$ & $38-45$ \\
\hline Total proteins, $\mathrm{g} / \mathrm{l}$ & $81.1 \pm 1.1 / 83.9 \pm 1.8$ & $80.0 \pm 1.4 / 82.6 \pm 1.4$ & $79.8 \pm 2.9 / 84.1 \pm 1.9$ \\
\hline Urea, $\mathrm{mmol} / \mathrm{l}$ & $3.14 \pm 0.16 / 3.88 \pm 0.27$ & $3.21 \pm 0.31 / 3.56 \pm 0.06$ & $3.41 \pm 0.25 / 3.54 \pm 0.34$ \\
\hline Creatinine, $\mu \mathrm{mol} / 1$ & $78.4 \pm 2.9 / 86.3 \pm 3.4$ & $78.7 \pm 2.7 / 89.3 \pm 6.8$ & $84.8 \pm 5.3 / 85.4 \pm 5.3$ \\
\hline Cholesterol, $\mathrm{mmol} / \mathrm{l}$ & $6.15 \pm 0.16 / 7.20 \pm 0.39^{*}$ & $5.87 \pm 0.18 / 6.59 \pm 0.19^{*}$ & $5.99 \pm 0.27 / 6.75 \pm 0.29$ \\
\hline Glucose, mmol/1 & $2.75 \pm 0.06 / 2.55 \pm 0.04$ & $2.39 \pm 0.06 / 2.36 \pm 0.04$ & $2.87 \pm 0.09 / 2.91 \pm 0.22$ \\
\hline Alkaline phosphatase, $\mathrm{U} / 1$ & $60.6 \pm 5.2 / 82.6 \pm 6.5^{*}$ & $63.5 \pm 4.7 / 71.6 \pm 6.2$ & $67.2 \pm 5.2 / 103.4 \pm 7.4^{* *}$ \\
\hline Alanine aminotransferase, $\mathrm{U} / \mathrm{l}$ & $29.4 \pm 2.4 / 31.5 \pm 1.9$ & $30.8 \pm 1.4 / 31.9 \pm 2.5$ & $34.1 \pm 2.9 / 38.6 \pm 2.8$ \\
\hline Aspartate aminotransferase, U/1 & $64.4 \pm 4.8 / 64.7 \pm 3.9$ & $58.7 \pm 4.0 / 76.8 \pm 7.6$ & $62.9 \pm 3.9 / 71.6 \pm 4.4$ \\
\hline$\gamma$--Glutamyltransferase, U/1 & $22.5 \pm 1.8 / 31.6 \pm 2.9^{*}$ & $20.9 \pm 1.2 / 37.1 \pm 5.8^{*}$ & $18.5 \pm 0.8 / 26.9 \pm 1.8^{* * *}$ \\
\hline $\begin{array}{l}\text { Middle molecule peptides, } \\
\text { relative units }\end{array}$ & $0.46 \pm 0.03 / 0.57 \pm 0.03^{*}$ & $0.49 \pm 0.03 / 0.52 \pm 0.04$ & $0.49 \pm 0.05 / 0.66 \pm 0.05^{*}$ \\
\hline $\begin{array}{l}\text { Index of endogenous intoxication, } \\
\text { relative units }\end{array}$ & $19.1 \pm 0.9 / 24.6 \pm 0.04^{* * *}$ & $18.4 \pm 1.2 / 20.8 \pm 0.9$ & $16.6 \pm 0.7 / 22.9 \pm 1.2^{* * *}$ \\
\hline General calcium, mmol/l & $2.76 \pm 0.09 / 2.56 \pm 0.09$ & $2.84 \pm 0.09 / 2.60 \pm 0.10$ & $2.80 \pm 0.08 / 2.48 \pm 0.11$ \\
\hline Phosphorus inorganic, $\mathrm{mmol} / \mathrm{l}$ & $1.77 \pm 0.11 / 1.93 \pm 0.07$ & $1.92 \pm 0.07 / 1.74 \pm 0.11$ & $1.90 \pm 0.09 / 1.84 \pm 0.13$ \\
\hline Magnesium, mmol/L & $1.26 \pm 0.01 / 1.02 \pm 0.03^{* * *}$ & $1.36 \pm 0.03 / 0.99 \pm 0.02 * * *$ & $1.13 \pm 0.05 / 1.02 \pm 0.03$ \\
\hline Zinc, mmol/l & $52.7 \pm 2.51 / 34.0 \pm 3.24^{* * *}$ & $40.8 \pm 2.83 / 31.2 \pm 3.03^{* * *}$ & $41.2 \pm 1.91 / 31.7 \pm 2.42^{* *}$ \\
\hline Copper, $\mu \mathrm{mol} / 1$ & $17.5 \pm 0.84 / 13.9 \pm 0.33^{* *}$ & $18.7 \pm 0.71 / 15.4 \pm 1.44^{*}$ & $15.9 \pm 0.72 / 12.2 \pm 0.96^{*}$ \\
\hline Manganese, $\mu \mathrm{mol} / \mathrm{l}$ & $2.64 \pm 0.11 / 2.24 \pm 0.14$ & $3.43 \pm 0.07 / 3.06 \pm 0.18$ & $2.50 \pm 0.07 / 2.58 \pm 0.14$ \\
\hline Selenium, $\mu \mathrm{mol} / 1$ & $1.27 \pm 0.08 / 1.00 \pm 0.11^{*}$ & $1.41 \pm 0.13 / 1.00 \pm 0.08^{*}$ & $1.23 \pm 0.10 / 1.03 \pm 0.09$ \\
\hline Protein-bound iodine, $\mu \mathrm{g} \%$ & $4.10 \pm 0.17 / 3.80 \pm 0.24$ & $4.58 \pm 0.14 / 3.05 \pm 0.15^{* *}$ & $4.25 \pm 0.22 / 3.65 \pm 0.13^{*}$ \\
\hline
\end{tabular}

The low concentration of estradiol-17 $\beta$ and testosterone responsible for protein synthesis in the embryo and proliferation in the uterus tissues in cows (see Table 1), also indicated a disorder in the hormone-synthesizing function of ovaries in the cows with embryonic death. In the first month of gestation, the 
difference with control animals for estradiol-17 $\beta$ level was 45.0-85.5\%, reaching $352.0 \%$ at embryo death. When embryos developed, the blood testosterone concentration gradually increased from $1.63 \pm 0.21$ to $2.86 \pm 0.56 \mathrm{nmol} / 1$, or by $75.4 \%$ $(\mathrm{p}<0.001)$. In case of embryonic loss, the testosterone level in the first month of gestation did not differ significantly from those in healthy animals but lowered 2.5 times by the time of the embryo death.

In assessing the metabolic status of cows, it was found that genetically programmed formation and development of the embryo in the first 1.5 months of gestation occurred without pronounced changes in blood level of total proteins, cholesterol, glucose, calcium, and AST activity (Table 2). However, there was a gradual increase in urea concentration by $8.6 \%$, creatinine by $8.2 \%$, phosphorus by $7.3 \%$, middle molecule peptides by $6.5 \%$, AP activity by $10.9 \%$ ALT activity by $16.0 \%$, whereas GGT activity and endogenous intoxication index were $17.8 \%$ and $13.1 \%$ lower. These changes reflected the intensification of metabolic processes in dam cows already at the early stages of the embryo's placentation.

When the embryo died, we recorded an increase in blood protein concentration by $3.2-5.4 \%$, in urea by $9.8-23.6 \%$, in creatinine by $10.1-13.5 \%$, in cholesterol by $10.9-17.1 \%$, in middle molecule peptides by $6.1-34.7 \%$, in alkaline phosphatase activity by $12.8-36.3 \%$, in ALT by $3.6-13.2 \%$, in AST by 13.8-30.8 \%, in GGT by 45.4-77.5\%, and in the index of endogenous intoxication by $13.0-40.0 \%$ as compared to the control. Together, these indicators reflected functional disorders in the liver and kidneys of cows with embryonic loss manifested by syndromes of cholestasis and endogenous intoxication.

Increased endogenous intoxication in the animals with embryo death was associated with a deficiency of pro-oxidant bioelements and a decreased activity of the antioxidant defense system (see Tables 2, 3). In these cows, the blood concentrations of zinc, copper, manganese, selenium and protein-bound iodine was below the control by 9.7-27.2 \%, 17.6-23.3\%, 10.8-15.2 \%, 16.3-29.1\%, and 7.3-33.4\%, respectively.

Zinc is essential in DNA synthesis and repair, growth, reproduction, cell differentiation and migration, embryogenesis and immunogenesis [21-25]. Its biological properties are associated with induction of zinc-copper-dependent superoxide dismutase, protection of DNA and transcription proteins from free radicals, inhibition of proteinases, neutralization of bacterial lipopolysaccharides and toxic metals. With a deficiency of zinc, the secretion of sex and corticosteroid hormones decreases, cytokine expression and inflammation in the uterus increase, cell proliferation and growth of the embryo are suppressed. Copper determines the activity of copper-zinc-dependent superoxide dismutase, is a part of ceruloplasmin and acts as an antioxidant, protecting cellular structures from oxidative stress. With its deficiency, free radical oxidation is activated, and the hormone-producing function of the hypothalamus, pituitary gland and gonads is reduced, which leads to an increase in death and resorption of embryos $[23,24]$.

Deficiency of selenium and iodine as constituent components of biologically active compounds (glutathione peroxidase, iodothyronine deiodinase, thyroid hormones) is accompanied by an increased lipid peroxidation, general metabolic disorder, lowered activity of the pituitary-gonad system, cell growth and tissue differentiation, hormonogenesis and immunogenesis [26-31].

There were no significant differences in manganese blood concentration between the groups of animals, but we do not exclude the role of the deficiency of this microelement in embryonic mortality reported in some papers [32, 33].

The magnesium deficiency in the body also led to early embryonic death. When the embryo died, magnesium concentration in the blood of cows was 9.7-27.9\% below control. Apparently, the lack of magnesium reduces the 
energy potential of proliferating embryonic cells, metabolic activity and detoxification, enhances the synthesis of prostaglandins $E_{2}$ and $F_{2}$, causing endotheliosis and a decrease in the progesterone production in ovarium yellow body [34, 35].

A decrease in calcium blood level (by 7.2-11.4\% compared to the control) was characteristic of the cows with embryonic loss. Clear evidence of calcium specific effect on embryogenesis is lacking. Perhaps, calcium deficiency is manifested through the effect on the exchange of essential trace elements.

In clinical experiments [36, 37] it was shown that parenteral injections of zinc, copper, selenium and manganese salts contribute to $9-13 \%$ higher survival of embryos. Biologically necessary accumulation of bioelements (as well as other nutrients) in the embryo is completely determined by the metabolic status of the maternal organism [32]. It can be argued that the deficiency and imbalance in the bioelement status of lactating cows with embryonic loss is associated with higher milk productivity and increased excretion of trace elements from the body with milk. The daily milk yield was $20.2 \pm 1.21 \mathrm{~kg}$ in cows with physiological development of the embryo and $24.6 \pm 1.03 \mathrm{~kg}$ in the cows with manifestation of embryopathies, which was higher by $21.8 \%(\mathrm{p}<0.05)$.

Deficiency of essential microelements was accompanied by a weakening of antioxidant protection and increased activity of lipid peroxidation (LPO) (Table 3). A certain increase in free radical lipid oxidation, as it was evidenced by 6.4-8.9\% elevation in blood MDA concentration, was characteristic of cows with normal embryogenesis.

3. Functional state of antioxidant protection and lipid peroxidation in black-andwhite cows in normal gestation and at embryonic loss $(X \pm x$, OOO SP Vyaznovatovka, Nizhnedevitsky Region, Voronezh Province, 2014)

\begin{tabular}{l|c|c|c}
\hline \multicolumn{1}{c}{ Parameter } & \multicolumn{3}{c}{ Gestation, days } \\
\cline { 2 - 4 } & $19-23$ & $28-32$ & $38-45$ \\
\hline $\mathrm{MDA}, \mu \mathrm{mol} / \mathrm{l}$ & $1.24 \pm 0.11 / 1.79 \pm 0.14^{* *}$ & $1.35 \pm 0.10 / 2.14 \pm 0.19^{* *}$ & $1.32 \pm 0.10 / 1.83 \pm 0.11$ \\
$\mathrm{Catalase}, \mu \mathrm{mol} \mathrm{H}{ }_{2} \mathrm{O}_{2} / 1 \cdot \mathrm{min}$ & $29.7 \pm 0.9 / 21.6 \pm 0.8^{* * *}$ & $34.6 \pm 0.5 / 16.9 \pm 0.4^{* * *}$ & $31.4 \pm 0.5 / 20.9 \pm 0.8^{* * *}$ \\
$\mathrm{GPO}, \mathrm{mmol} \mathrm{GSH} / 1 \cdot \mathrm{min}$ & $18.2 \pm 0.9 / 13.5 \pm 0.9^{* * *}$ & $15.2 \pm 1.2 / 14.4 \pm 1.2$ & $17.3 \pm 0.5 / 11.9 \pm 1.1^{* * *}$ \\
$\mathrm{Vitamin} \mathrm{E}, \mathrm{mmol} / 1$ & $36.9 \pm 3.3 / 27.2 \pm 2.2^{*}$ & $35.9 \pm 2.5 / 24.0 \pm 1.3^{* * *}$ & $34.8 \pm 2.9 / 23.8 \pm 1.9^{* *}$ \\
Vitamin $\mathrm{C}, \mathrm{mmol} / 1$ & $19.8 \pm 1.4 / 8.5 \pm 0.9^{* * *}$ & $17.7 \pm 0.6 / 9.9 \pm 0.6^{* * *}$ & $17.9 \pm 0.8 / 13.4 \pm 1.1^{* *}$ \\
$\mathrm{~N}$ o t e. Before and after the slash there are physiological formation and death of the embryo, respectively. GSH - & \\
reduced glutathione, MDA - malonic dialdehyde, GPO - glutathione peroxidase. & \\
$*, * *, * * * \mathrm{p}<0.05, \mathrm{p}<0.01, \mathrm{p}<0.001$ compared to control (physiological formation). \\
\hline
\end{tabular}

In cows with embryonic loss, MDA concentration exceeded the indicator in the control animals by $44.3 \%$ on days $19-23$ of gestation and by $58.5 \%$ on days 28-32, and MDA level remained high after the death of the embryo, exceeding the control values by $38.6 \%$ on days $38-45$. Higher accumulation of toxic products of LPO appears to be associated with enhanced formation of reactive oxygen species (ROS), LPO activation, and insufficient antioxidant protection. Catalase activity in these animals, as compared to the control, was $26.5 \%$ lower in implantation and $51.2 \%$ lower in the early placentation. These differences were $33.4 \%$ on days $38-45$ in the cows with clinically confirmed fetal death. At embryonic loss, GPO activity were $25.8 \%$ lower during implantation and $31.2 \%$ at embryo death, vitamin $\mathrm{E}$ was 26.3 and $31.6 \%$ lower, respectively, and vitamin $\mathrm{C}$ was 57.1 and $25.1 \%$ lower than in healthy animals. Deficiency of enzyme and non-enzyme antioxidants should be associated with their high consumption for detoxification and elimination of actively generated aggressive free radicals and with the depletion of the reserves of the antioxidant protection system (AOPS) due to deficiency of essential bioelements. Violation of dynamic equilibrium in the LPO-AOPS, accompanied by excessive accumulation of toxic LPO products, leads to the development of oxidative stress characterized by irreversible oxidative modification and damage to proteins and DNA [38, 
39], which should be considered as a sign of embryopathy development in cows.

The adverse effects of oxidative stress on embryo are related not only to the direct embryotoxicity of aggressive free radicals, but also to their negative effect on the hormone-synthesizing structures of gonads and the immune system.

Already on days 19-23 of gestation in the blood of cows with the risk of embryonic loss, an increase in the total number of leukocytes (by $12.9 \%$ ) and their neutrophil forms (by $14.0 \%$ ) was noted (Table 4), which could indicate intoxication or development of the inflammatory process in the genitals. The population of monocyte which are active phagocytes, precursors of tissue macrophages and producers of complement components also increased by $77.8 \%$.

The development of toxic, allergic and autoimmune response to embryo death showed a 2-fold elevation in the number of blood of eosinophils, which ensure the destruction of histamine, toxins of protein origin, foreign proteins and immune complexes. CIC (antigen-antibody complex) concentration in the animals of this group was 2.96 times higher than in cows with normal pregnancy. An excess in CIC accumulation, associated with allergic reactions, leads to destruction of the tissues in genitals and can affect the developing embryo.

4. Indicators of immune defense and natural resistance in cows of black-and-white breed in the physiological formation of the embryo and its death $(X \pm x$, OOO SP Vyaznovatovka, Nizhnedevitsky district, Voronezh region, 2014)

\begin{tabular}{|c|c|c|c|}
\hline \multirow{2}{*}{ Parameter } & \multicolumn{3}{|c|}{ Gestation, days } \\
\hline & $19-23$ & $28-32$ & $38-45$ \\
\hline Leucocytes, $\times 10^{9} / 1$ & $8.5 \pm 0.50 / 9.6 \pm 0.44$ & $9.0 \pm 0.28 / 10.0 \pm 0.62$ & $8.5 \pm 0.34 / 10.0 \pm 0.46^{*}$ \\
\hline Neutrophils, \% & $28.6 \pm 1.8 / 32.6 \pm 2.1$ & $30.8 \pm 2.1 / 27.8 \pm 1.4$ & $29.3 \pm 1.7 / 35.0 \pm 2.9$ \\
\hline Monocytes, \% & $2.7 \pm 0.2 / 4.8 \pm 0.2^{* * *}$ & $2.4 \pm 0.2 / 3.3 \pm 0.1 * *$ & $2.9 \pm 0.2 / 3.3 \pm 0.2$ \\
\hline Eosinophils, \% & $5.2 \pm 0.3 / 10.6 \pm 0.9 * * *$ & $6.4 \pm 0.3 / 14.0 \pm 1.2 * * *$ & $5.6 \pm 0.3 / 13.3 \pm 1.1^{* * *}$ \\
\hline Lymphocytes, \% & $63.2 \pm 2.1 / 52.0 \pm 3.5$ & $60.4 \pm 2.3 / 54.9 \pm 3.4$ & $62.1 \pm 2.8 / 48.4 \pm 2.6^{* *}$ \\
\hline PAL, $\%$ & $68.8 \pm 2.9 / 58.8 \pm 4.3$ & $69.4 \pm 2.9 / 63.9 \pm 4.3$ & $76.1 \pm 2.6 / 69.7 \pm 3.7$ \\
\hline Immunoglobulins, g/1 & $29.3 \pm 0.7 / 21.8 \pm 1.1$ *** & $28.6 \pm 0.8 / 20.8 \pm 0.9 * * *$ & $27.0 \pm 0.7 / 20.4 \pm 1.4^{* * *}$ \\
\hline $\mathrm{CIC}, \mathrm{g} / 1$ & $0.23 \pm 0.02 / 0.68 \pm 0.06^{* * *}$ & $0.29 \pm 0.02 / 0.61 \pm 0.02 * * *$ & $0.30 \pm 0.02 / 0.57 \pm 0.04^{* * *}$ \\
\hline BABS, $\%$ & $82.2 \pm 1.9 / 61.4 \pm 5.3^{* *}$ & $73.6 \pm 2.8 / 52.7 \pm 3.8^{* * *}$ & $79.0 \pm 2.9 / 57.5 \pm 3.2^{* * *}$ \\
\hline LABS, \% & $0.48 \pm 0.03 / 0.29 \pm 0.02 * * *$ & $0.40 \pm 0.03 / 0.28 \pm 0.02 * *$ & $0.45 \pm 0.03 / 0.26 \pm 0.02 * * *$ \\
\hline \multicolumn{4}{|c|}{$\begin{array}{l}\text { N ot e. Before and after the slash there are physiological formation and death of the embryo, respectively. PAL - } \\
\text { phagocytic activity of leukocytes, CIC - circulating immune complexes, BABS - bactericidal activity of blood } \\
\text { serum, LABS - lysozyme activity of blood serum. } \\
*, * *, * * * \mathrm{p}<0.05, \mathrm{p}<0.01, \mathrm{p}<0.001 \text { compared to control (physiological formation). }\end{array}$} \\
\hline
\end{tabular}

The blood CIC concentration was inversely related to the phagocytic activity of the leukocytes which was $14.5 \%$ lower at the death of the embryo compared to the control. The high CIC level, together with a decreased activity of polynucleated leukocytes testified both to the congestion of the phagocytic system and to the increased migration of functionally immature neutrophils from the bone marrow under the influence of interleukin-1, the amount of which increases during pregnancy [18]. In cows with the manifestation of embryonic mortality, the relative amount of blood lymphocytes was $14.5 \%$ lower, and the total immunoglobulin level lowered by $25.6 \%$. The latter can be related both to the oppression of their synthesis, and to the increase in CIC formation and utilization.

In animals with improper embryonic development, a deficiency in adaptation to stress caused by pregnancy was combined with a decrease in the indices of humoral factors of natural resistance. Blood bactericidal activity and lysozyme activity was 25.3 and $39.6 \%$ less than in the control, which correlated with inhibition of phagocytic leukocyte reaction.

On days 28-32 of gestation, previously revealed differences in the indicators of cellular and humoral immunity in different groups, as a whole, remained unchanged. When the embryo died, the number of blood leukocytes increased by $11.1 \%$, the number of monocytes, eosinophils and CIC concentration were $37.5 \%, 218.7 \%$ and 210.0 higher, respectively, as compared to 
the control, whereas PAL (phagocytic activity of leukocytes), number of lymphocytes, BA and LS lowered by $7.9 \%, 9.1 \%, 28.4 \%$ and $30.0 \%$, respectively. Similar results were obtained on days 38-45. The observed changes in the immune status of mother-cows reflect a strong reaction of the body to endotoxins and embryo antigens, which testify to immunodeficiency and reduced adaptive abilities of animals in early gestation.

It is known that the microbiocenosis of the vagina plays a significant role in ensuring the homeostasis of the reproductive organs, their colonization resistance and protection of the reproductive tract [39-41]. The main representatives of its normoflora are lacto- and bifidobacteria, acting as antagonists of conditionally pathogenic and pathogenic microorganisms to suppress their growth and reproduction. The protective effect of lactobacilli and bifidobacteria is due to secretion of a significant amount of lactic and other organic acids, various bacteriocins, vitamins and other bioactive substances, and to a direct stimulating effect on immunocompetent structures of the reproductive tract, local and general immunoreactivity of the body. The stability of the vaginal microbiocenosis is ensured by the coordinated interaction of the endocrine and immune systems in which any violation leads to dysbiosis and a replacement of normal microflora by conditionally pathogenic and pathogenic microorganisms.

In normal gestation, the total microbial contamination of the vaginal mucus was quite stable and varied from $509.7 \pm 24.3$ to $573.2 \pm 48.4 \mathrm{CFU} / \mathrm{ml}$. The presence of lactobacilli was recorded in 66.6-83.3\% of animals at the titers of $10^{-4.08}$ to $10^{-3.38}$. Bifidobacteria, a part of normoflora possessing high colonization antagonistic and adhesive activity, were found in $100 \%$ of animals with normal embryo formation. When embryo died, on days 28-45 of gestation the bifidobacteria were detected only in 50-75\% of cows with the titers 2.22-2.95 times lower than in healthy animals.

Reduction of colonization of the genital organs by normoflora was accompanied by an increase in the counts of enterobacteria (Escherichia coli, Enterococcus faecalis) and fungi in the mucus. The frequency of enterobacteria increased from 10.0-16.6 \% to 33.3-70.0 \%, while fungi were 1.4-2.0 times frequent. The $\mathrm{pH}$ of the vaginal mucus increased from $7.3 \pm 0.16-7.62 \pm 0.07$ to $8.25 \pm 0.15-8.63 \pm 0.18$.

Thus, in the polyfactorial etiology of early embryo loss in lactating cows, the pathophysiological determinants are the deficiency and imbalance of essential mineral elements, as well as oxidative stress and endogenous intoxication, which leads to endocrine and immune deficiency and is accompanied by a violation of immune and trophic relationships in the mother-embryo system. Means and methods for correction of diselementosis, antioxidant, endocrine and immune status should be developed to prevent embryonic loss and improve fertility in high-yielding dairy cows.

\section{R E F E R E N C ES}

1. Milovanov V.K., S ok olovskaya I.I. V knige: Teoriya i praktika vosproizvedeniya zhivotnykh [In: Theoretical and practical aspects of animal reproduction]. Moscow, 1984: 47-68 (in Russ.).

2. Humblot P., Camons S., Martal J., Charlery J., Jeanguyot N., Thibi e r M., S a s s e r R.G. Pregnancy-specific protein B, progesterone concentrations and embryonic mortality during early pregnancy in dairy cows. J. Reprod. Fertil., 1988, 83: 215-223 (doi: 10.1530/jrf.0.0830215).

3. Ro ma no J.E., To m p s o $n$ J.A., K ra e m e r D.C., W e s thus i n M.E., For res t D.W., T o m a s z w e s k i M.A. Early pregnancy diagnosis by palpation per rectum: Influence on embryo/fetal viability in dairy cattle. Theriogenology, 2007, 67: 486-493 (doi: 10.1016/j.theriogenology.2006.08.011).

4. Chaudhary A.K., Purohit G.N. Ultrasonographic detection of early pregnancy loss in 
dayri cows. J. Anim. Sci. Adv., 2012, 2(8): 706-710.

5. D y u l'g e r G.P. Veterinariya sel'skokhozyaistvennykh zhivotnykh, 2012, 11: 30-35 (in Russ.).

6. Yanchukov I., Panferov V., Moroz T. Molochnoe i myasnoe skotovodstvo, 2011, 8: 24 (in Russ.).

7. Chomaev A., Mityashova O. Zhivotnovodstvo Rossii, 2013, 9: 41-42. Available http://www.zzr.ru/?q=node/3274. No date (in Russ.).

8. B elik S.V. Razrabotka sposobov povysheniya oplodotvoryaemosti korov $v$ usloviyakh molochnykh kompleksov. Avtoreferat kandidatskoi dissertatsii [Ways to increase fertility in cows on dairy farms. PhD Thesis]. Saratov, 2016 (in Russ.).

9. B u t le r W.R. Review: effect of protein nutrition on ovarian and uterine physiology in dairy cattle. J. Dairy Sci., 1998, 81: 2533-2539 (doi: 10.3168/jds.S0022-0302(98)70146-8).

10. Yaniz J., Lopez-Gatius F., Bech-Sabat G., Garcia-Jspierto J., Serrano B., S a n t o la ri a P. Relationships between milk production, ovarian function and fertility in high producing dairy herds in north-eastern Spain. Reprod. Domest. Anim., 2008, 43: 38-43 (doi: 10.1111/j.1439-0531.2008.01227.x).

11. Se ifi H.A., Mohri M., Farzaneh N., Ne mati H., Nejhad S.V. Effect of anionic salts supplementation on blood $\mathrm{pH}$ and mineral, energy metabolism, reproduction and production in transition dairy cows. Res. Vet. Sci., 2010, 89: 72-79 (doi: 10.1016/j.rvsc.2010.01.013).

12. C row e M.A., Willa m s E.J. Triennial lactation symposium: effects of stress on postpartum reproduction in dairy cows. J. Anim. Sci., 2012, 90: 1722-1727 (doi: 10.2527/jas.2011-4674).

13. Nezhdanov A.G., Mikhalev V.I., Lozovaya E.G., Dy ul'ge r G.P. Voprosy normativno-pravovogo regulirovaniya $v$ veterinarii, 2014, 3: 120-124 (in Russ.).

14. Retskii M.I., Shakhov A,G., Shushlebin V.I., Samotin A.M., Misailov V.D., Chusova G.G., Zolotarev A.I., Degtyarev D.V., Ermolova T.G., Chudnenko O.V., Bliznetsova G.N., Savina E.A., Dolgopolov V.N., Belyaev V.I., Meshcheryakov N.P., Filatov N.V., Samokhin V.T., Dzhamaludinova I.N., Mamaev N.Kh., Donnik I.M., Tatarchuk A.T., Malygina A.A., Leont'ev L.B., Ivanov G.I., Grigor'eva T.E., Argunov M.N., Kuznetsov N.I., Fedyuk V.I., Derezina T.N., Ovcharov V.V., Kalyuzhnyi I.I., Ryzhkova G.F., Shkuratova I.A., Arte m'e va S.S., Kaverin N.N. Metodicheskie rekomendatsii po diagnostike, terapii i profilaktike narushenii obmena veshchestv u produktivnykh zhivotnykh [Recommendations on diagnostics, therapy and prevention of metabolic disorders in productive animals]. Voronezh, 2005 (in Russ.).

15. Shakhov A.G., Mas'yanov Yu.V., Retskii M.I., Brigadirov Yu.N., Anufriev A.I., Biryukov M.V., Pershina S.I., Kardashov A.M., Petrova M.G., Batishcheva E.A., Belyaev V.I., Zolotarev A.I., Bliznetsova G.N., Buzla ma V.S., Suleimanov S.M., Fedorov YU.N., Borzenko E.V., Khanis A.Yu., Borzenko T.V., Artemov B.T., Efanova L.I., Manzhurina O.A., Panin A.N., Makarov Yu.A., Donnik I.M., Tatarchuk A.T., Balakirev N.A., Maiorov A.I., Emel'yanenko P.A., Kirillov A.K., Maiorov M.A., Goryachev A.A., Evdo k i mov V.V., Voronin E.S., Sisyagin P.N., Is aev V.V., Redzhepova G.R., Gorbunov A.P., Boyarintsev L.E., Klimenko V.V., Kaverin N.N., Artem'eva S.S., Topuriya G.M., Topuriya L.Yu., Zhukov A.P., Kalyuzhnyi I.I., Mamaev N.Kh., Dzhamaludshova I.N. Metodicheskie rekomendatsii po otsenke immunnogo statusa zhivotnykh [Recommendations for assessing the immune status of animals]. Voronezh, 2005 (in Russ.).

16. Dobrokhotova Yu.E., Gonkovskaya L.V., Bakhereva I.V., Svit ich O.A., M a lus he n k o S.V. Akusherstvo i ginekologiya, 2016, 7: 5-8 (doi: 10.18565/aig.2016.7.5-10) (in Russ.).

17. N e s y a e v a E.V. Akusherstvo i ginekologiya, 2005, 2: 3-7 (in Russ.).

18. S h i r s h e v S.V. Mekhanizmy immunoendokrinnogo kontrolya protsessov reproduktsii. Tom 1 [Mechanisms of immunoendocrine control of reproduction. V. 1]. Ekaterinburg, 2002 (in Russ.).

19. Miya moto A., Shirasuna K., Shimizu T., Matsui M. Impact of angiogenic and innate immune systems on the corpus luteum function during its formation and maintenance in ruminants. Reprod. Biol., 2013, 13(4): 272-278 (doi: 10.1016/j.repbio.2013.09.006).

20. Wiltbank M.C., Souza A.H., Carvalho P.D., Cunha A.P., Giorda n o J.O., Fricke P.M., B a e s G.M., D i s k i n M.G. Physiological and practical effects of progesterone on reproduction in dairy cattle. Animal, 2014, 8(1): 78-81 (doi: $10.1017 /$ S1751731114000585).

21. B e le t s k a y a E.N., O n u l N.M. Mikroelementy $v$ meditsine, 2014, 15(2): 22-28 (in Russ.).

22. Skal'ny i A.V., Z a lavi na S.V., Efi mov S.V. Vestnik Orenburgskogo gosudarstvennogo universiteta, 2006, 2: 78-81 (in Russ.).

23. Fav'e M., Khinindzher-Fav'e I. Mikroelementy v meditsine, 2002, 3(4): 2-6 (in Russ.).

24. Neve J. Clinical implications of trace elements in endocrinology. Biol. Trace Elem. Res., 
1992, 32: 173-185 (doi: 10.1007/BF02784602).

25. Chen Y.H., Zhao M., Chen X., Zhang Y., Wang H., Huang Y.Y., Wang Z., $\mathrm{Z}$ h a ng Z.H., $\mathrm{Z}$ h ang C., $\mathrm{Xu}$ D.X. Zinc supplementation during pregnancy protects against lipopolysaccharide-induced fetal growth restriction and demise through its anti-inflammatory effect. J. Immunol., 2015, 30: 454-463 (doi: 10.4049/jimmunol.1103579).

26. Mo is e e nok A.G., P ityuk E.V., M o is e e nok E.A. V sbornike: Pitanie i obmen veshchestv [In: Nutrition and metabolism]. Grodno, 2002: 70-98 (in Russ.).

27. Arthur J.R., B e rmano G., Mitchell J.H., Hesketh J.E. Regulation of selenoprotein gene expression and thyroid hormone metabolism. Biochem. Soc. Trans., 1996, 24: 384-388 (doi: 10.1042/bst0240384).

28. B e r r y M.J., B a n u L., La r s e n P.R. Type I iodothyronine deiodinase is a selenocysteinecontaining enzyme. Nature, 1991, 349: 438-440 (doi: 10.1038/349438a0).

29. K a mada H., H od a t e K. Effect of dietary selenium supplementation on the plasma progesteron concentration in cows. J. Vet. Med. Sci., 1998, 60(1): 133-135.

30. S a m o k h i n V.T. Profilaktika narushenii mikroelementov u zhivotnykh [Prevention of microelement metabolism disorders in animals]. Voronezh, 2003 (in Russ.).

31. Ufe $\mathrm{r}$ C., W a ng C.C. The roles glutathione peroxidases during embryo development. Front. Mol. Neurosci., 2011, 4: 12 (doi: 10.3389/fnmol.2011.00012).

32. S c h e fe rs J. Fetal and perinatal mortalities associated with manganese deficiency. Proc. Minnesota Dairy Health Conference. St. Paul, Minnesota, USA, 2011: 70-74.

33. Hostet le r C., K in c a id R., Mira nd o M. The role essential trace elements in embryonic and fetal development in livestock. Vet. J., 2003, 166(2): 125-139 (doi: 10.1016/S10900233(02)00310-6).

34. S ka l'ny i A.V. Khimicheskie elementy $v$ fiziologii $i$ ekologii cheloveka [Chemical elements in human physiology and ecology]. Moscow, 2004 (in Russ.).

35. T s a 11 a g o v a E.V. Farmateka, 2013, 20: 84-87 (in Russ.).

36. S a les J.N.S., P e re i r a R.V.V., B i c a 1 h o R.C., B a r u s e 11 i P.S. Effect of injectable copper, selenium, zinc and manganese on the pregnancy rate of crossbred heifers (Bos indicus $\times$ Bos tansus) synchronized for timed embryo transfer. Livestock Sci., 2011, 142: 59-62.

37. Mund e 11 L.R., J a e g e r J.R., W aggon e r J.W., S t e ve n s on J.S., Grieger D.M., Pacheco L.A., Bolte J.W., Aubel N.A., Eckerle G.J., Macek M.J., Ens le y S.M., Havenga L.J., O ls o n K.C. Effects of prepartum and postpartum bolus injections of trace minerals on performance of beef cows and calves grazing native range. The Professional Animal Scientist, 2012, 28: 82-88 (doi: 10.15232/S1080-7446(15)30318-1).

38 . Ze n k ov N.K., La nki n V.Z., M e n's h i k ova E.B. Okislitel'nyi stress: biokhimicheskii $i$ patofiziologicheskie aspekty [Oxidative stress: biochemical and pathophysiological aspects]. Moscow, 2001 (in Russ.).

39. Ku z net s o v a I.V. Akusherstvo i ginekologiya, 2016, 3: 116-121 (doi: 10.18565/aig.2016.3.116121) (in Russ.).

40. K ras no zh e nov E.P., A k h r e m e n k o Ya.A. Kolonizatsionnaya rezistentnost' organizma cheloveka $v$ norme i pri patologii [Colonization resistance of the human body in normal and pathological conditions]. Kirov, 2013. Available http://books.eee-science.ru/downloads/kolonizacionnajarezistentnost-orga. No date (in Russ.).

41. Chernova N.I., Perlomutrov Yu.N. Akusherstvo i ginekologiya, 2013, 10: 104-108. Available http://www.aig-journal.ru/ru/archive/article/12348. No date_(in Russ.). 